\title{
Evaluation of children followed up for Covid-19 in a tertiary hospital
}

\author{
Esra Akyüz ÖZKAN ${ }^{*}$ (i) , Emine Hafize ERDENIZ² \\ ${ }^{1}$ Department of Pediatrics, Faculty of Medicine, Ondokuz Mayıs University, Samsun, Turkey \\ ${ }^{2}$ Department of Pediatric Infectious Disease, Faculty of Medicine, Ondokuz Mayıs University, Samsun, Turkey
}

\begin{abstract}
$\begin{array}{llll}\text { Received: } 26.09 .2020 & \bullet \quad \text { Accepted/Published Online: 09.12.2020 • } & \text { Final Version: } 14.03 .2021\end{array}$
Abstract

Since December 2019, 2019 outbreak of coronavirus (Covid-19) spread all over the world as well as in Turkey. In this study, we aimed to investigate the clinical and laboratory effects of covid 19 disease on children. The epidemiological, laboratory, radiological, and treatment features of the 30 pediatric patients with covid-19 evaluated retrospectively. The median age of the patients was 10 years, boys and girls ratio was 1.5 (18/12). Of the patients, $80.7 \%$ had family contact and $11.5 \%$ had comorbidity. The most common symptom was fever (84.6\%), and cough was the second frequency $(57.7 \%)$. All patients except 1 patient had a mild course, 5 were asymptomatic. One patient needed intensive care who had underlying chronic disease. Neutropenia was the most common laboratory anomaly (36.6\%). Increased D-dimer levels were observed in 9 patients (30\%), decreased leukocyte was in 7 patients (23.3\%) and increasedlactate dehydrogenaz level was in 8 patients (26.6\%). Chest computed tomography was taken 14 patients who had an abnormal chest X-rays, and ground-glass opacities were seen in 6 patients (20\%). Hydroxychlorachine, azithromycin and other antibiotic treatments were given to the necessary patients. The mean PCR negative time in the treated symptomatic group was $8.8+5.34$ day, while in the untreated asymptomatic group $12+5.19$ day and there was no statistically significant difference $(\mathrm{p}=0.154)$. The correlation between PCR negative time and clinical, laboratory, and radiological findings was examined and no correlation was found. In conclusion, pediatric covid 19 is mostly transmitted by family contact and has a mild course if there is no underlying disease. The most common symptoms are fever and cough. Ground glass densities on lung tomography are similar to adult. More conservative approaches may be preferred in children.
\end{abstract}

Keywords: children, Covid-19, clinical symptoms, epidemiological features

\section{Introduction}

As of mid-December 2019, a new type of coronavirus infection has emerged in Wuhan, China and quickly spread over a wide area (Jiatong et al., 2020). Genome sequence was isolated from a patient on January 10, 2020, and it was shown that this is a novel coronavirus strain. The World Health Organization (WHO) announced this pathogen to the world as "2019 novel coronavirus (2019-nCoV) (She et al., 2020)" two days later and Covid 19 has reached a pandemic stateon March 12, 2020. There were two severe coranovirus outbreaks: severe acute respiratory syndrome (SARS) in 2003 and Middle East respiratory syndrome (MERS) in 2012 (WHO., 2020).

In Turkey, the first case appeared later than in many European countries. The first case was reported on 11 March and increased very rapidly and peaked in mid-April (WHO., 2020).
Clinical manifestations of Covid19 range from asymptomatic to critical illness. The fever and cough are the most common symptoms (Chen et al., 2020). Clinical findings in pediatric patients are not typical and are relatively mild compared to adult patients. Children are usually asymptomatic. Upper respiratory tract symptoms such as fever, malaise, dry cough, nasal congestion and runny nose are observed in some patients, while gastrointestinal symptoms such as diarrhea, abdominal pain and nausea-vomiting may be observed in few patients (Lu et al., 2020). Although most cases are reported to recover completely within 1 to 2 weeks, acute respiratory distress syndrome, metabolic acidosis, coagulation disorders and septic shock have also been reported in rare cases (Qiu et al., 2020).

In this study, we aimed to contribute to science by retrospectively examining the laboratory, radiological, 
epidemiological and therapeutic features of children with covid-19 who were admitted to our hospital.

\section{Material and method}

Thirty patients under the age of 18 years, diagnosed with Covid-19 in the Department of Pediatrics, Faculty of Medicine, Ondokuz Mayis University between March 2020 and July 2020 were included in the study. Ethics committee approval for the study was received from the Ethics Committee of Ondokuz Mayıs University (2020/514). Patient data were analyzed retrospectively according to medical records in the electronic database. Patients over the age of 18 and patients whose data could not be reached were excluded. All patients were evaluated in terms of laboratory and radiology results, epidemiological and demographic characteristics, following-up during hospitalization and treatment responses. At the beginning of the pandemic, a diagnosis and treatment guide were published by Turkish Ministry of Health's Scientific Committee.

Combined naso-oropharyngeal swabs were obtained for the reverse transcription polymerase chain reaction (RT-PCR) test from patients who met the criteria specified in the guideline. Complete blood count, serum biochemical test (including kidney and liver function, lactate dehydrogenase (LDH), myocardial enzymes, coagulation profile, ferritin, Creactive protein $(\mathrm{CRP})$, procalcitonin and chest X-rays were studied from the admitted patients. Chest computed tomography (CT) was performed in patients with lower respiratory tract findings or poor clinical prognosis.

At the beginning of the pandemic, the provincial sanitation committee requested the hospital follow-up of covid-positive patients. As the number of patients increased later, patients in good condition were followed at home. In this study all patients were followed up at the hospital. Patients who had no fever for at least 48 hours, had no abnormalities in laboratory tests that required hospitalization, and whose respiratory findings recovered were discharged.

As a treatment in these patients; supportive therapy, monitoring of lung, liver, kidney and heart functions, fever control, antiviral treatments, oxygen therapy, corticosteroids and antibiotic therapy in case of bacterial superinfection were applied.

The statistical analyses were carried out by Statistical Package for Social Sciences (SPSS 21 Inc., Chicago, IL, USA). Parametric variables were compared using the Student's t test. Variables were expressed as mean \pm SD and percentages and $p$ value $<0.05$ was considered to indicate statistical significance. Bivariate associations of the variables were assessed using Pearson's correlation coefficients.

\section{Results}

Between March and August, we observed 30 children with covid-19 positive. The median age was 10 years. The boy's and girl's ratio were $1.5(18 / 12)$. Of the patients, $80.7 \%$ had family contact and $11.5 \%$ had comorbidity (Table 1 ).

Table 1. Demographic characteristics of patients with coronavirus disease 2019

\begin{tabular}{|l|c|}
\hline Epidemiologic data & Total (n=30) \\
\hline Age (year) & 10 y $(0.1-$ \\
$17.7 y)$ \\
\hline $\mathbf{0 - 1}$ y (n, \%) & $1(3.3 \%)$ \\
\hline $\mathbf{1 - 5}$ y (n, \%) & $6(20 \%)$ \\
\hline $\mathbf{5 - 1 0 y ~ ( n , ~ \% ) ~}$ & $6(20 \%)$ \\
\hline $\mathbf{1 0 - 1 8 y}(\mathbf{n}, \%)$ & $17(56.6 \%)$ \\
\hline Male (n, \%) & $18(60 \%)$ \\
\hline Female (n, \%) & $12(40 \%)$ \\
\hline Famil ymembers with covid-19 (n, \%) & $21(70 \%)$ \\
\hline Comorbidity (n, \%) & $3(10 \%)$ \\
\hline
\end{tabular}

The most common symptom was fever (73.3\%), and cough was the second frequency (50\%). No patients had runny rose. All patients except 1, had a mild course, 5 were asymptomatic. One patient needed intensive care who had underlying chronic disease (Table 2). One patient was newborn, transmitted from his mother, had only subfebrile fever for 2 days and recovered without treatment.

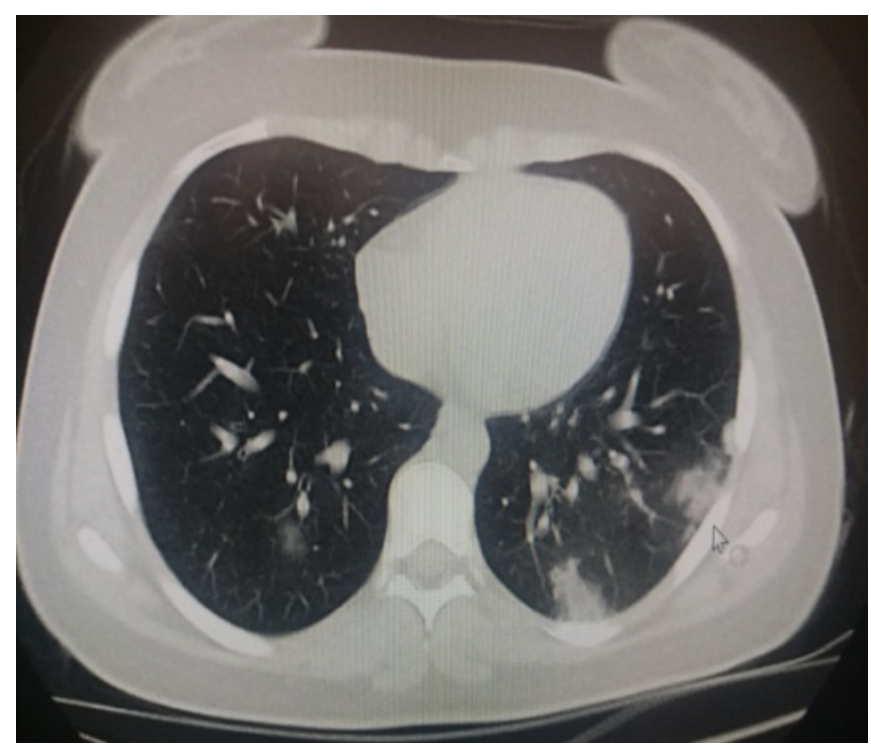

Fig. 1. Chest computed tomography image of children with coronavirus disease 2019, 15-year-old girl showing ground glass densities in the middle and lower lobes of both lungs

The laboratory and radiological findings were summarized in Table 3. Neutropenia was the most common laboratory anomaly (36.6\%). Increased D-dimer levels were observed in 9 patients (30\%), decreased leukocyte was in 7 patients $(23.3 \%)$ and increased LDH level was in 8 patients $(26.6 \%)$. Chest CT was taken 14 patients who had an abnormal X-rays, and ground-glass opacities were seen in 6 patients $(20 \%)$ (Figure 1). 
Özkan et al. / J Exp Clin Med

Table 2. Clinical features of patients with coronavirus disease 2019

\begin{tabular}{|l|c|}
\hline Symptoms & $\mathbf{n ~ ( \% )}$ \\
\hline Fever & $22(73.3 \%)$ \\
\hline Cough & $15(50 \%)$ \\
\hline Dyspnoea or tachypnoea & $4(13.3 \%)$ \\
\hline Sore throat & $8(26.6 \%)$ \\
\hline Vomiting or diarrhoea & $2(6.6 \%)$ \\
\hline Headache & $8(26.6 \%)$ \\
\hline Myalgia & $10(33.3 \%)$ \\
\hline Runny nose & 0 \\
\hline Anosmia & $1(3.3 \%)$ \\
\hline Asymptomatic & $5(16.6 \%)$ \\
\hline Intensive care need & $1(3.3 \%)$ \\
\hline
\end{tabular}

Table 3. Laboratory and radiological findings of patients with coronavirus disease 2019

\begin{tabular}{|c|c|}
\hline \multicolumn{2}{|l|}{$\begin{array}{c}\text { Laboratory tests (reference } \\
\text { values) }\end{array}$} \\
\hline White blood cells $(4-10 \times 10$ cells per $L)$ & $5.76 \pm 2.06$ \\
\hline Decraced $(n, \%)$ & $7(23.3 \%)$ \\
\hline Lymphocytes $(1.2-3.3 \times 10$ cells per $L)$ & $2.38 \pm 1.07$ \\
\hline Decraced $(n, \%)$ & $3(10 \%)$ \\
\hline Neutrophil $(1.8-6.98 \times 10$ cells per $L)$ & $2.72 \pm 1.53$ \\
\hline Decraced $(n, \%)$ & $11(36.6 \%)$ \\
\hline Hemoglobin, g/dL (11.5-14) & $12.83 \pm 1.69$ \\
\hline Platelet count $\left(\times 10^{9}\right)(150-300)$ & $259.2 \pm 82.58$ \\
\hline Blood urea, mg/dL (5-24) & $9.55 \pm 4.31$ \\
\hline Creatinine, $\mathrm{mg} / \mathrm{dL},(0.31-0.47)$ & $.53 \pm .24$ \\
\hline Aspartat transferase, U/L (8-46) & $19.64 \pm 14.46$ \\
\hline Alanin amino transferase, $\mathrm{U} / \mathrm{L},(0-40)$ & $27.04 \pm 11.83$ \\
\hline C-reactive protein $(0-5)$ & $7.14 \pm 11.34$ \\
\hline Increased $(\mathrm{n}, \%)$ & $2(6.6 \%)$ \\
\hline Procalcitonin, ng/mL (0.05-0.5) & $.83 \pm 3.28$ \\
\hline Increased $(\mathrm{n}, \%)$ & $2(6.6 \%)$ \\
\hline Troponin T, ng/mL, (0.00-0.12) & $.00 \pm .028$ \\
\hline Increased (n, \%) & $1(3.3 \%)$ \\
\hline D-dimer, $\mu \mathrm{g} / \mathrm{mL},(0-500)$ & $990.57 \pm 1528.43$ \\
\hline Increased $(\mathrm{n}, \%)$ & $9(30 \%)$ \\
\hline Lactat mmol/L, (0.4-1.4) & $1.71 \pm 1.02$ \\
\hline Lactate dehydrogenaz U/L, (0-300) & $324.45 \pm 130.37$ \\
\hline Increased $(\mathrm{n}, \%)$ & $8(26.6 \%)$ \\
\hline Ferritin ng/mL (21-274) & $164.77 \pm 218.63$ \\
\hline Increased (n, \%) & $3(10 \%)$ \\
\hline \multicolumn{2}{|l|}{ Radiography } \\
\hline Pulmonary ground-glass opacities & $6(20 \%)$ \\
\hline PCR negation time (day) & $8.86(1-20)$ day \\
\hline
\end{tabular}

\section{Discussion}

SARS-CoV-2 is a highly contagious virus that causes the most pneumonia (Parry., 2020). It can be transmitted from an infected person or by an asymptomatic carrier. Although the main route of transmission is by droplets, it can also be transmitted through contact, the digestive system and through the conjunctiva (Riou et al., 2020). It has been shown that body fluids and infectious droplets can contaminate the human conjunctival epithelium ( $\mathrm{Lu}$ et al., 2020). Incubation period ranges from 1 to 14 days (Hui et al., 2020). Although the number of cases began later than in many other countries, Covid 19 outbreak in Turkey has increased very fast. The number of cases were high, but the number of deaths were relatively low compared to other countries. Schools were vacationed with the first case seen in Turkey, then a curfew was imposed on children under the age of 15 . So, the number of cases were low in children.

Covid 19 has a milder prognosis in children in terms of clinical symptoms and consequences compared to adults (Garazzino et al., 2020). Some theories have been proposed about the reason for this (Lu et al., 2020). One of these theories is that children are less likely than adults to have an excessive immune response and cytokine storm (Qiu et al., 2020). Another theory; highly expressed angiotensin converting enzyme 2 (ACE2) proteins in alveolar type 2 cells are fewer or immature in children compared to adults (Zhou et al., 2020). ACE2 is expressed not only in lung AT2 cells, but also in intestinal epithelial cells in the ileum and colon as well as upper esophagus and stratified epithelial cells. Thus, the intestinal symptoms of SARS-CoV-2 may be associated with the invasion of ACE2-expressing intestinal epithelial cells (Zhang et al., 2020). Another theory is that frequent infection of children with other viral and bacterial infections improves their immune system and therefore coronovirus disease is milder (Guo et al., 2020). The clinic of our patients was benign except for one and did not need intensive care. One of our patients with an underlying chronic disease was followed up in intensive care. Our patient was previously followed up due to cerebral palsy, and followed up in high flow in intensive care. All of our patients were discharged in good health. Yang et al (Yang et al., 2020) reported that three $(1.8 \%$ ) of 171 children treated at Wuhan Children's Hospital needed intensive care, and all of them had underlying diseases. The average age of our patients was 10 years old and most of them were between the ages of 10 and 18. In a pediatric case series from China that included 2143 children, the median age at pediatric diagnosis was 7 years (Dong et al., 2020).

This virus can infect children of all ages, including newborn babies (Wei et al., 2020). Our youngest patient was 22 days old and got the virus through family transmission. He had no complaints except for subfebrile fever for two days and followed up with the mother without treatment. Our patient was breastfeeding and her mother was treated with hydroxychlorachine. In the study by $\mathrm{Lu} \mathrm{X}$ et al ( $\mathrm{Lu}$ et al., 2020), 18\% of the children were under 1 year old (Lu et al., 2020). In another study, the most severe course of the disease was between 0-1 years. (Dong et al., 2020). Jiehao et al (Jiehao et al., 2020) reported three cases of newborns by February 20, while there are 80,000 cases in total. One of the patients had fever and cough for 3 days, the other had a runny nose and vomiting for a week, the other patient born from an infected mother had respiratory distress. Pregnancy is not a risk factor for severe Covid-19 (WHO., 2020). However, having Covid19 during pregnancy can have an impact on fetal distress, possible premature birth and respiratory distress in the newborn (Zhu et al., 2020). In the study of Dong et al (Dong et al., 2020) $56.6 \%$ of 2143 patients were found to be male. In current study $60 \%$ were boys. 
Table 4. The correlation between pcr negative time and laboratory parameters in children with coronavirus disease 2019

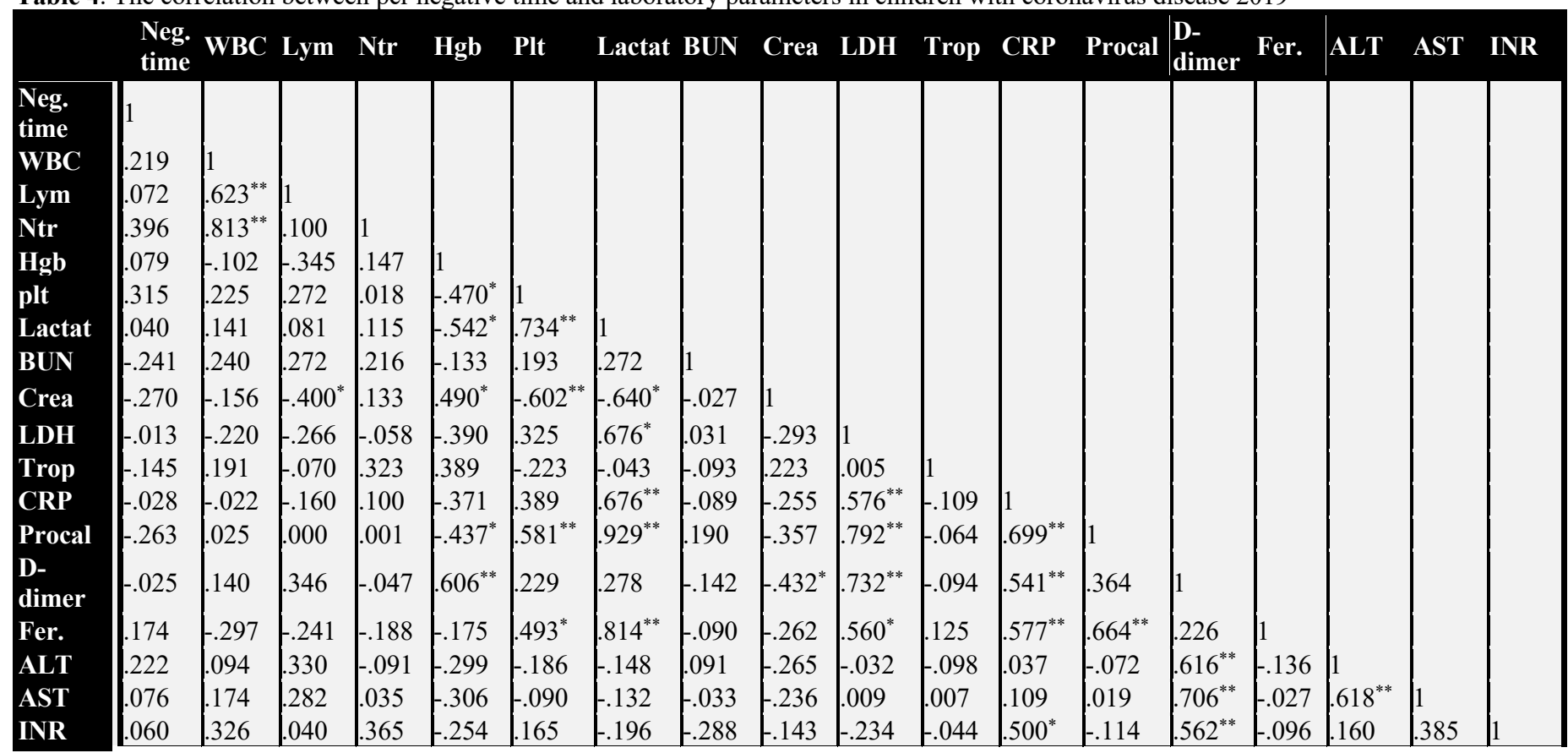

**. Correlation is significant at the 0.01 level (2-tailed).

*. Correlation is significant at the 0.05 level (2-tailed).

Neg. Time: negation time, WBC: Whitebloodcells, lym: Lymphocytes, ntr: Neutrophil, hgb: hemoglobin, plt: platelet, BUN: Blood urea, crea: creatinin, ldh: lactate dehydrogenaz, trop: troponin, crp: c-reactive protein, procal: procalsitonin, ALT: Alanine aminotransferases, AST:

Aspartate Aminotransferase

INR: International Normalized Ratio in Standardization of Prothrombin Time Measurement

Table 5: The correlation between pcr negative time and clinical symptoms and radiological imaging children with coronavirus disease 2019

\begin{tabular}{|c|c|c|c|c|c|c|c|c|c|c|c|c|c|}
\hline & Age & Gender & Fever & Cough & Tachypnea & Myalgia & $\begin{array}{l}\text { Sore } \\
\text { throat }\end{array}$ & $\begin{array}{l}\text { Head } \\
\text { ache }\end{array}$ & Vomiting & Diarrhea & $\begin{array}{l}\text { Underlying } \\
\text { disease }\end{array}$ & CT & $\begin{array}{l}\text { Neg. } \\
\text { time }\end{array}$ \\
\hline $\begin{array}{l}\text { Age } \\
\text { Gender }\end{array}$ & $\begin{array}{l}1 \\
-.118\end{array}$ & 1 & & & & & & & & & & & \\
\hline Fever & -.028 & .033 & 1 & & & & & & & & & & \\
\hline Cough & -.315 & -.168 & -.149 & 1 & & & & & & & & & \\
\hline Tachypnea & -.108 & -.247 & -.114 & .365 & 1 & & & & & & & & \\
\hline Myalgia & $-.587^{* *}$ & .256 & .118 & .037 & .101 & 1 & & & & & & & \\
\hline Sorethroat & $-.438^{*}$ & .283 & .053 & .065 & .178 & $.501^{* *}$ & 1 & & & & & & \\
\hline Headache & $-.428^{*}$ & .116 & .053 & .234 & $.409^{*}$ & $.672^{* *}$ & $.458^{*}$ & 1 & & & & & \\
\hline Vomiting & 377 & -.134 & .018 & -182 & -.018 & -.123 & -.217 & .159 & 1 & & & & \\
\hline Diarrhea & -.253 & .141 & -.019 & .099 & -.234 & .318 & .030 & .228 & .285 & 1 & & & \\
\hline $\begin{array}{l}\text { Underlying } \\
\text { disease }\end{array}$ & 171 & $-.461^{*}$ & .182 & 149 & $.409^{*}$ & -.337 & -.053 & -.053 & .222 & -.234 & 1 & & \\
\hline CT & .016 & -.187 & .046 & $489^{*}$ & $.548^{* *}$ & -.158 & -.071 & .083 & -.186 & -.313 & .350 & 1 & \\
\hline $\begin{array}{l}\text { Negation } \\
\text { time }\end{array}$ & -.253 & -.361 & -.303 & .039 & .066 & -.092 & -.055 & .094 & .121 & .010 & .143 & .04 & 1 \\
\hline
\end{tabular}

**. Correlation is significant at the 0.01 level (2-tailed)

*. Correlation is significant at the 0.05 level (2-tailed). CT: Computed tomography

Table 6. The mean PCR negative time in treated and untreated group

\begin{tabular}{|c|c|c|c|}
\hline \multicolumn{2}{|c|}{$\begin{array}{c}\text { Treated } \\
\text { group }\end{array}$} & $\begin{array}{c}\text { Untreated } \\
\text { group }\end{array}$ & $\begin{array}{c}\text { P } \\
\text { value }\end{array}$ \\
\hline $\begin{array}{c}\text { Mean PCR } \\
\text { negative } \\
\text { time }\end{array}$ & $8.5+5.2$ & $12.7+4.5$ & 0.154 \\
\hline
\end{tabular}

Among the pediatric patients in our study, 5 patients $(16.6 \%)$ were asymptomatic. In the study by Qiu et al. (Qiu et al., 2020), less than a third of the patients were asymptomatic. According to Korkmaz et al (Korkmaz et al., 2020), 21\% of patients were asymptomatic. In the study conducted by Dong et al. (Dong et al., 2020) on 2143 children, it was reported that more than $90 \%$ of them had an asymptomatic or mild course. The prevalence of severe or critical disease in the same study; $10.6 \%$ in children $<1$ year old, $4.2 \%$ in $1-5$ years old, $4.1 \%$ in $11-15$ years old and $4.1 \%$ in $16-17$ years old (Dong et al., 2020). Most of our patients were in family contact, only 5 of them had no contact history.

The most common clinical findings were fever and cough (73.3\%, 50\% respectively), vomiting and diarrhea (6.6\%) were seen in fewer patients. Similar to our study, the most common symptoms in the study of $\mathrm{Lu} \mathrm{X}$ et al (Lu et al., 2020) 


\section{Özkan et al. / J Exp Clin Med}

were cough (48.5\%), pharyngeal erythema (46.2\%) and fever (41.5\%). In the study of Dong et al (Dong et al., 2020), cough, fever, sore throat, myalgia, sneezing and fatigue were the most common symptoms. According to the literature, prevalence of pneumonia with Covid $19(53 \%)$ is higher than with H1N1 influenza $(11 \%)$ and similar to the prevalence with SARS (65\%) (Babyn et al., 2004). In this study 6 patients had pneumonia (20\%), 1 of them (3.3\%) needed intensive care treatment that previously followed up for cerebral palsy. Although patients with underlying diseases are more sensitive to Covid 19 according to the literature, only 3 of our patients had an underlying chronic disease (Xia et al., 2020).

Two patients $(6.6 \%)$ had initially diarrhea or vomiting. In a study conducted in China, gastrointestinal symptoms such asvomiting, abdominal pain and diarrhea were observed in $2 \%$ to $10 \%$ of Covid 19 patients (Yeo et al., 2020).

Covid 19 can affect vital organs such as the heart, although it is mild in children. An increase in cardiac enzymes has been reported (Qiu et al., 2020). In our study, we did not have any patients with cardiac involvement.

Neutropenia was the most common laboratory abnormality (11 patents, $36.6 \%$ ) and 3 patients $(10 \%)$ had lymphopenia. According to Lu X et al (Lu et al., 2020) lymphopenia was one of the most common hematological abnormalities. Other abnormal laboratory results include increased liver, muscle and cardiac enzymes, D dimer, CRP, LDH and procalcitonin. Increased D dimer level was detected in 9 patients (30\%). Xia et al (Xia et al., 2020) suggested that $80 \%$ cases had elevated prokalsitonin levels. In a study by Henry et al (Henry et al., 2020) summarizing the findings of 12 different studies on 66 children, while the leukocyte count was normal in $69.2 \%$ of the children, neutrophilia was observed in $4.6 \%$ and neutropenia in $6.0 \%$. Only 2 children (3.0\%) had lymphocytopenia. In the same review, CRP was increased in $13.6 \%$ and procalcitonin in $10.6 \%$ of cases.

In current study, procalcitonin increased in 2 patients $(6.6 \%)$. One of them was our patient followed up in intensive care. This patient received antibiotic treatment in addition to antiviral therapy. The procalcitonin value of our second patient was slightly higher (0.658) and antibiotics were not started.

Ground glass appearance and pulmonary consolidation are radiological findings seen in covid 19. These findings are usually located in the lower lobe, peripheral localization is observed, and has a bilateral and multifocal distribution (Li et al., 2020). In this study, patients with respiratory distress were taken CT and ground-glass appearance was observed on thoracic tomography in 6 patients $(20 \%)$. Korkmaz et al (Korkmaz et al., 2020) showed that $20 \%$ of patients had these tomographic abnormalities. In the study of Lu et al (Lu et al., 2020), ground-glass opacity was seen in a third of 171 diagnosed children. Xia and colleagues (Xia et al., 2020) studied 20 children by CT and found that $16(80 \%)$ had some abnormalities, including halo marks, and 12 patients $(60 \%)$ had ground glass opacities. Zhang et al (Zhang et al., 2020) found that ground-glass opacity was $3 \%$.

Supportive therapies, including antibiotics for bacterial superinfections and oxygen therapy, are recommended for the treatment of pediatric patients with Covid-19. However, there are some antiviral treatments that can be used (Lu et al., 2020). There are publications suggesting that azithromycin and hydroxychloroquine treatments reduce the viral load. Gautret et al (Gautret et al., 2020) showed that hydroxychloroquine therapy is significantly associated with viral load reduction or loss in Covid-19 patients, and its effect is enhanced when azithromycin is added. The administration of plasma isolated from the patients who had previously recovered from Covid19 , interferons and intravenous immunoglobulins also can be used for treatment in these patients (Jin et al., 2020).

In this study, with the recommendation of the scientific committee, hydroxychloracine treatment was used if the patient was symptomatic and over 15 years of age, and azithromycin treatments were used if under 15 years of age. These patients were taken for daily electrocardiogram evaluation and no complications developed such as QT prolongation. For the patient followed up in the intensive care unit, also antibiotic treatments were applied. If the patient is asymptomatic, no treatment was given. There were 5 asymptomatic children. In symptomatic group that given hydroxychloracine or azithromycin treatment, mean PCR negative time was $8.8+5.34$ day, while in the untreated asymptomatic group it was $12+5.19$ day and there was no statically significant difference $(\mathrm{p}=0.154)$.

We investigated the correlation between PCR negative time and laboratory, radiological and clinical findings in patients with covid-19 and there was no correlation.

In conclusion, pediatric covid 19 is mostly transmitted by family contact and has a mild course if there is no underlying disease. Their symptoms are similar to other viral infections, the most common symptoms are fever and cough. Ground glass densities on lung tomography are similar to adult. There was no statically significant difference between treated and untreated group in terms of mean PCR negative time.

\section{Acknowledgment}

None

\section{Conflict of Interest}

None

\section{References}

1. Babyn, PS., Chu, WC., Tsou, IY., Wansaicheong, GK., Allen, U., Bitnun, A., Chee, TS., Cheng, FW., Chiu, MC., Fok, TF., Hon, EK., Gahunia, HK., Kaw, GJ., Khong, PL., Leung, CW., Li, AM., Manson, D., Metreweli, C., Ng, PC., Read, S., Stringer, DA., 2004. Severe acute respiratory syndrome (SARS): chest radiographic features in children.Pediatr. Radiol.34,47-58. 


\section{Özkan et al. / J Exp Clin Med}

2. Chen, N., Zhou, M., Dong, X., Qu, J., Gong, F., Han, Y., Qiu, Y., Wang, J., Liu, Y., Wei, Y., Xia, J., Yu, T., Zhang, X., \& Zhang, L. 2020. Epidemiological and clinical characteristics of 99 cases of 2019 novel coronavirus pneumonia in Wuhan, China: a descriptive study. Lancet. 395:507-513.

3. Dong, Y., Mo, X., Hu, Y., Qi, X., Jiang, F., Jiang, Z., Tong, S., 2020. Epidemiology of COVID-19 among children in China. Pediatrics. 145, 20200702.

4. Garazzino, S., Montagnani, C., Donà, D., Meini, A., Felici, E., Vergine, G., Bernardi, S., Giacchero, R., Lo, Vecchio A., Marchisio, P., Nicolini, G., Pierantoni, L., Rabbone, I., Banderali, G., Denina, M., Venturini, E., Krzysztofiak, A., Badolato, R., Bianchini, S., Galli, L., Villani, A., Castelli-Gattinara, G.; Italian SITIP-SIP Pediatric Infection Study Group; 2020. Multicentre Italian study of SARS-CoV-2 infection in children and adolescents, preliminary data as at 10 April 2020. Euro. Surveill.25,2000600.

5. Gautret, P., Lagier, JC., Parola, P., Hoang, VT., Meddeb, L., Mailhe, M., Doudier, B., Courjon, J., Giordanengo, V., Vieira, VE., Tissot Dupont, H., Honoré, S., Colson, P., Chabrière, E., La Scola, B., Rolain, JM., Brouqui, P., Raoult, D., 2020. Hydroxychloroquine and azithromycin as a treatment of COVID19: results of an open-label non-randomized clinical trial. Int. J. Antimicrob. Agents.56, 105949.

6. Guo, L., Ren, L., Yang, S., Xiao, M., Chang, D., Yang, F., Dela Cruz, CS., Wang, Y., Wu, C., Xiao, Y., Zhang, L., Han, L., Dang, S., Xu, Y., Yang, QW., Xu, SY., Zhu, HD., Xu, YC., Jin, Q., Sharma, L., Wang, L., Wang, J., 2020 Profiling early humoral response to diagnose novel coronavirus disease (COVID-19). Clin. Infect. Dis. 71, 778-785.

7. Henry, BM., Lippi, G., Plebani, M., 2020. Laboratory abnormalities in children with novel coronavirus disease 2019. Clin. Chem. Lab. Med. 16,16.

8. Hui, DS., Azhar, EI., Madani, TA., Ntoumi, F., Kock, R., Dar, O., Ippolito, G., Mchugh, TD., Memish, ZA., Drosten, C., Zumla, A., Petersen, E., 2020. The continuing 2019-nCoV epidemic threat of novel coronaviruses to global health-the latest 2019 novel coronavirus outbreak inWuhan, China. Int. J. Infect. Dis. 91,264266

9. Jiatong, S., Wenjun, L., 2020. Epidemiological characteristics and prevention and control measures of Corona Virus Disease 2019 in children. J. Trop. Med. 20,153-156.

10. Jiehao, C., Jin, X., Daojiong, L., Zhi, Y., Lei, X., Zhenghai, Q., Yuehua, Z., Hua, Z., Ran, J., Pengcheng, L., Xiangshi, W., Yanling, G., Aimei, X., He, T., Hailing, C., Chuning, W., Jingjing, L., Jianshe, W., Mei, Z., 2020. A Case Series of children with 2019 novel coronavirus infection: clinical and epidemiological features. Clin. Infect. Dis. 71, 1547-1551.

11. Jin, YH., Cai, L., Cheng, ZS., Cheng, H., Deng, T., Fan, YP., Fang, C., Huang, D., Huang, LQ., Huang, Q., Han, Y., Hu, B., Hu, F., Li, BH., Li, YR., Liang, K., Lin, LK., Luo, LS., Ma, J., Ma, LL., Peng, ZY., Pan, YB., Pan, ZY., Ren, XQ., Sun, HM., Wang, Y., Wang, YY., Weng, H., Wei, CJ., Wu, DF., Xia, J., Xiong, Y., Xu, HB., Yao, XM., Yuan, YF., Ye, TS., Zhang, XC., Zhang, YW., Zhang, YG., Zhang, HM., Zhao, Y., Zhao, MJ., Zi, H., Zeng, XT., Wang, YY., Wang, XH.; for the Zhongnan Hospital of Wuhan University Novel Coronavirus Management and Research Team, Evidence-Based Medicine Chapter of China International Exchange and Promotive Association for Medical and Health Care (CPAM)., 2020. A rapid advice guideline for the diagnosis and treatment of 2019 novel coronavirus (2019-nCoV) infected pneumonia (standard version). Mil. Med. Res.7, 4.

12. Korkmaz, MF., Türe, E., Dorum, BA.,Kılıç, ZB., 2020. The Epidemiological and Clinical Characteristics of 81 Children with
COVID-19 in a Pandemic Hospital in Turkey: an Observational Cohort Study. J. Korean. Med. Sci. 35, e236.

13. Li, W., Cui, H., Li, K., Fang, Y., L,i S., 2020. Chest computed tomography in children with COVID-19 respiratory infection. Pediatr. Radiol.50,796-799.

14. Lu, X., Xing, Y., Wong, GW., 2020. COVID-19: lessons to date from China. Arch Dis Child. Arch. Dis. Child.0,1-5.

15. Lu, X., Zhang, L., Du, H., Zhang, J., Li, YY., Qu, J., Zhang, W., Wang, Y., Bao, S., Li, Y., Wu, C., Liu, H., Liu, D., Shao, J., Peng, X., Yang, Y., Liu, Z., Xiang, Y., Zhang, F., Silva, RM., Pinkerton, KE., Shen, K., Xiao, H., Xu, S., Wong, GWK.; Chinese Pediatric Novel Coronavirus Study Team., 2020. SARS-CoV-2 Infection in Children. N. Engl. J. Med.38,1663-1665.

16. Parry, J., 2020. Wuhan: Britons to be evacuated as scientists estimate 44000 cases of 2019 nCOV in the city. Brit. Med. J.368,351.

17. Qiu, H., Wu, J., Hong, L., Luo, Y., Song, Q., Chen, D., 2020.Clinical and epidemiological features of 36 children with coronavirus disease 2019 (COVID-19) in Zhejiang, China:an observational cohort study. Lancet. Infect. Dis. 20, 689-696.

18. Qiu, H., Wu, J., Hong, L., Luo, Y., Song, Q., Chenet, D., 2020. Clinical and epidemiological features of 36 children with coronavirus disease 2019 (COVID-19) in Zhejiang, China: an observational cohort study. Lancet. Infect. Dis.20,689-696.

19. Riou, J., Althaus, CL., 2020. Pattern of early humantohuman transmission of Wuhan 2019 novel coronavirus $(2019 \mathrm{nCoV})$, December 2019 to January 2020. Euro. Surveill. 25,7-11.

20. She, J., Liu, L., Liu, W., 2020. COVID-19 epidemic: Disease characteristics in children. J. Med. Virol.92,747-754.

21. Wei, M., Yuan, J., Liu, YU., Fu, T., Yu, X., Zhang, ZJ., 2020. Novel coronavirus infection in hospitalized infants under 1 year of age in China. JAMA. 14, 14.

22. WHO. Report of the WHO-China Joint Mission on Coronavirus Disease $2019 \quad$ (COVID-19. (https://www.who.int/docs/defaultsource/coronaviruse/whochina-joint-mission-on-covid-19-finalreport.pdf; accessed: March 19, 2020), 2020

23. World Health Organization (WHO). WHO characterizes COVID19 as a pandemic [EB/OL]. Geneva, Switzerland: World Health Organization; 2020.

24. World Health Organization. Novel coronavirus (COVID-19) situation. https://covid19.who.int/. Updated 2020. Accessed May $18,2020$.

25. Xia, W., Shao,J., Guo, YU., Peng, X., Li, Z., Hu, D., 2020. Clinical and CT features in pediatric patients with COVID-19 infection: different points from adults. Pediatr. Pulmonol. 05, 05.

26. Yang, PU., Liu, P., Li, D.,Zhao D., 2020. Corona Virus Disease 2019, a growing threat to children? J. Infect. 80,671-693.

27. Yeo, C., Kaushal, S., Yeo, D., 2020. Enteric involvement of coronaviruses: is fecal-oral transmission of SARS-CoV-2 possible. Lancet Gastroenterology\& Hepatology. 5,335-337.

28. Zhang, C., Gu, J., Chen, Q., Deng, N., Li, J., Huang, L., Zhou, X., 2020. Clinical and epidemiological characteristics of pediatric SARS-CoV-2 infections in China: A multicenter case series. PLoS. Med.17, e1003130. 10

29. Zhang, H., Kang, Z., Gong, H., Xu, D., Wang, J., Li, Z., et al., 2020. The digestive system is a potential route of 2019-nCov infection: a bioinformatics analysis based on single-cell transcriptomes. Gut.0,1-9. 
30. Zhou, P., Yang, XL., Wang, XG., Hu, B., Zhang, L., Zhang, W., Si, HR., Zhu, Y., Li, B., Huang, CL., Chen, HD., Chen, J., Luo, Y., Guo, H., Jiang, RD., Liu, MQ., Chen, Y., Shen, XR., Wang, X., Zheng, XS., Zhao, K., Chen, QJ., Deng, F., Liu, LL., Yan, B., Zhan, FX.,

31. Wang, YY., Xiao, GF., Shi, ZL., 2020. A pneumonia outbreak associated with a new coronavirus of probable bat origin. Nature.579,270-273.

32. Zhu, H., Wang, L., Fang, C., Peng, S., Zhang, L., Chang, G., Xia, S., Zhou, W., 2020. Clinical analysis of 10 neonates born to mothers with 2019-nCoV pneumonia. Transl. Pediatr.9,51-60. 